\title{
Collaborative Governance and Sound Governance Actors to Reduce Covid 19 In Indonesia
}

\author{
Muhammad Yusran Amir', M. Thahir Haning ${ }^{2}$, M.Yunus ${ }^{3}$ \\ \{yusranfkmunhas@gmail.com ${ }^{1}$ \} \\ Student of Doctoral Degree, Public Administration, FISIP Hasanuddin University ${ }^{1,2}$ \\ Public Administration, FISIP Unhas ${ }^{3}$
}

\begin{abstract}
The number of Covid 19 cases has shown significant increase in Indonesia. Therefore, there should be a proper policy to reduce the number of covid 19 in Indonesia. The policy must be based on theory. The theories of collaborative Governance and sound governance are a possible solution for reducing covid 19 in Indonesia. This research aimed to examine the theory of collaborative Governance and Sound Governance to reduce Covid 19 in Indonesia specifically on the Actor-analysis. The method of the research was a literature review with a synthesis of qualitative research i.e, meta-study specifically on meta-theory method (the analysis of theory) of the collaborative Governance and Sound Governance. We combined the Meta Study with other relevant Journals and Books. The result showed that there were three actors in Collaborative Governance in reducing the pandemic of covid19 in Indonesia, i.e. 1) Government 2) Private institution and 3). Civil Society. Another significant actor needed to be added was International Actor. Therefore, Sound Governance gave the theory by emphasizing the need of international actor (Global Actor). The Sound Governance mentioned four actors i.e. 1) International actor, 2) Government, 3) Private Institution and 4) Civil Society. The Global Actor such as international companies and institution such as World Health Organization, World blanket would play significant role as we hoped that they would invent Vaccine-Covid 19 that was accessible for all human-being in the world. The collaboration of four actors would play significant role in reducing the pandemic of covid 19 not only in Indonesia but also in the world.
\end{abstract}

Keywords: Collaborative Governance, Sound Governance, Covid 19.

\section{Introduction}

There are many problems faced by public administration on tackling the corona virus in Indonesia. The crucial issue is to make an effective public policy to handle the pandemic of Covid-19 in Indonesia. COVID-19 is a virus that can cause acute respiratory distress syndrome that leads to lung failure and death[1]. The Covid-19 virus was announced to be a global pandemic by the Secretary General of World Health Organization (WHO) Mr Tedros Adhanom Ghebre Yesus on March 11th, 2020. The virus was originally found in Wuhan China in late 2019. Then, the virus was widely spread across the globe and reached Indonesia [2].

The data from WHO on December 15, 2020 showed that there were 220 countries affected by the virus. 71.051805 people had been identified positive cases. The number of deaths reached to 1.608648 People.2 The number of cases of Covid-19 continued to increase. Based 
on the data on 15 December 2020.Government of Indonesia (GOI) stated that there were 617.820 cases of positive corona virus, 505.836 people were recovered, and 18.819 people were death[3]. The government had tried to handle the progress of Covid 19 by issuing a Presidential Decree No. 7 of 2020 concerning Task Force (Satgas) for the Acceleration of Corona Virus Disease 2019 (COVID-19), which was later revised to Presidential Decree No. RI. 9 of 2020 with the main task of anticipating the impact of covid-19 in Indonesia and strengthening the implementation of the task force for acceleration of COVID-19 in Indonesia. [4, 5]

However, the government had many difficulties to handle the virus due to lack of capacity and competency at the street level of bureaucracy. The policy of the government of Indonesia had shown uneffective and unefficient to reduce the covid 19 in Indonesia. Therefore, the government should do a collaboration from many sectors. The collaboration stated here is collaborative governance and sound Governance. Collaborative Governance is a policy that involved several factors such as government, private institution and Civil Society to solve the problem of covid 19 in Indonesia[6].

The pandemic of covid 19 is a global pandemic, then there is a must for the government to cooperate with international actor/global network. The collaboration was explained by Farazmand and Carter [7] They stated that there were four main actors to be involved to be successful in sound governance i.e., 1). International Actor. 2). Government, 3). Private institution and 4).Civil Society.

This research aimed to examine the theory of collaborative Governance and Sound Governance to reduce Covid 19 in Indonesia specifically on the actor-analysis. There is a need to formulate a new policy that is based on the theory. Therefore, the researchers tried to analyze the policy of Covid 19 from public administration perspective using the theory of Collaborative Governance and Sound Governance.

There were two research questions i.e. 1) Who were the actors from the perspective of Collaborative Governance to reduce covid 19 in Indonesia? 2). Who was the Actor from the perspective of Sound Governance to reduce covid 19 in Indonesia?

\section{Research Methods}

The method of the research was a literature review with a synthesis of qualitative research i.e, by reviewing the existing literature on collaborative Governance and Sound Governance research. We combined the main theory of collaborative Governance and Sound Governance with other relevant Journals and articles [8]. Armed with a working definition of collaborative governance and sound governance, we collected a wide range of case studies from the literature. We systematically reviewed journals across a wide range of disciplines, including journals in public health, PubMed, medical journal, public administration, public policy, social etc.

We also conducted key word electronic searches using a wide variety of search terms, including those described above and many more (e.g., "covid 19," "Collaborative Governance," "Sound Governance"'). Of course, we also followed upon the literature cited in the cases we discovered. Ultimately, our model is built on an analysis of many different cases from Indonesia, Taiwan and South Korea. 


\section{Results and Discussion}

The discussion begins by understanding the definition of collaborative governance, Therefore, there will be no misperception on the concept of collaborative governance in this paper., according to Ansell And Gash (2008) collaborative governance is a form of governance structure, where one or more public agencies directly relate to non-state stakeholders. In a formal decision-making process, which is oriented on consensus, deliberative and leads to formulation or implementation of public policies or can also be in program management or public assets." [6].

Related to the definition, Ansell and Gash (2008) stated that there were six important criteria of collaborative governance i.e.

a. The forum is initiated by public agencies or institutions.

b. Participants in the forum include non-state actors. Participants engage directly in decision making and are not merely "consulted" by public agencies.

c. The forum is formally organized and meets collectively.

d. The forum aims to make decisions by consensus (even if consensus is not achieved in practice), and

e. The focus of collaboration is on public policy or public management.

There are many aspects of collaborative governance. Therefore, we narrow the analysis into stakeholder analysis. Why? We try to analyze the core of collaborative governance and end up with three researchers i.e.

a. Smith $(1998,61)$ For Example, Argues That Collaboratives Involve "'Representation by Key Interest Groups' [9].

b. Reilly $(1998,115)$ describes collaborative efforts as a type of problem solving that involves the "shared pursuit of government agencies and concerned citizens."[10].

c. Connick and Innes $(2003,180)$ define collaborative governance as including

"representatives of all relevant interests."[11].

Based on these three experts of collaborative governance, we narrow the analysis into stakeholder analysis. To clearly explain about stakeholder analysis, then the first step is to define what is stakeholder? Ansell and Gash (2007) defines stakeholder as follows:

"We use the term "stakeholder" to refer both to the participation of citizens as individuals and to the participation of organized groups. For convenience, we will also here after use the term "stakeholder" to refer to both public agencies and non-state stakeholders, though we believe that public agencies have a distinctive leadership role in collaborative governance. Our definition of collaborative governance also sets standards for the type of participation of nonstate stakeholders."

3.1 A Model of Stakeholder Analysis for Collaborative Governance and Sound Governance to Reduce Covid 19 In Indonesia

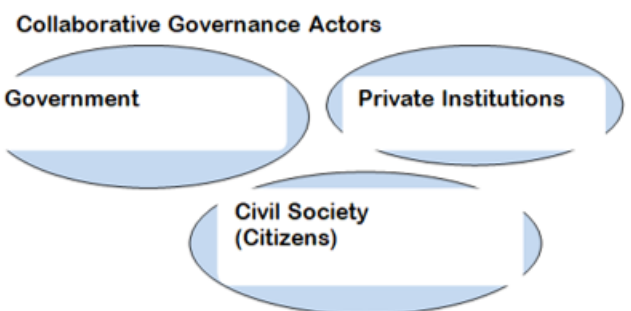

Fig 1. A Model of Collaborative Governance Actors (Ansell and Gash, 2008) 
Figure 1 provides a visual representation of our central findings. The model has three Actors-Government (Public Institution), Private Institutions (Company), and Civil Society (Citizens). Each of these three variables has connected one another. In fact, the core idea of collaborative governance is the power-sharing among the stakeholders (Actors). Power sharing explicitly also indicates resource-sharing among the stakeholders. The figure below discusses a model of sound governance.

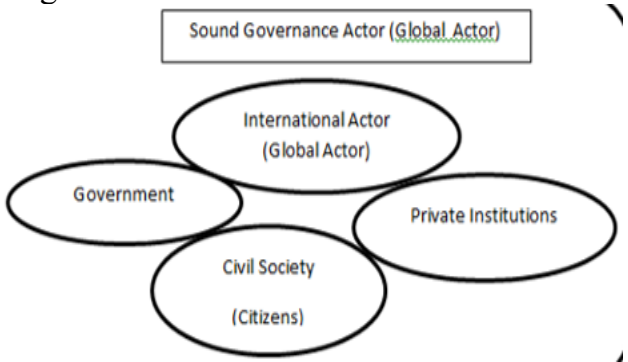

Fig 2. A model of Sound Governance Actors Farazmand and Carter [7]

Figure 2 provides a visual representation of our central findings. The model has four Actors: International Actor, Government (Public Institution), Private Institutions (Company), and Civil Society (Citizens).

\subsection{Collaborative Governance and Sound Governance Actors to Reduce Covid 19 In Indonesia}

The following paragraph discusses the role of the government, Private Institution, Civil Society/Community and International Actor.

\section{Government}

Collaborative governance can work effectively if the government leadership brings the participating actors together and facilitating collaboration and cooperation Ansell and Gash [6]; Vangen and Huxham [12]. The researchers tried to analyze the role of the government in Indonesia, and we tried to take a lesson-learned from Taiwan, and South Korea. We found two articles that discussed the role of collaborative governance in Indonesia. Article from Suhudiyah [13]discussed the importance of government to reduce covid 19 in Indonesia. There were five important stakeholders that needed to be included i.e. academic, business, community, government and media. These five stakeholders were called "Penta Helix Actor'"[13].

Another article emphasized the need of cooperation and coordination of central government and local government to make Collaborative Governance succeed. Megawati, et al. [14] showed that the local government played a crucial role to implementation the LargeScale Social Restrictions (PSBB) in Surabaya. The same result was found by Ginanjar [15]showed that local government played an important role to reduce covid 19 especially on the implementation of the law no 32/2004 article 22 on regional autonomy in Indonesia.

Indonesia should learn from the success of Collaborative Governance to reduce covid on the other countries. Two countries were analyzed on the success of the government on collaborative governance i.e., Taiwan and South Korea. Yuen Wai Hung [16] stated that Taiwan succeeds to fight covid 19 through government initiatives and collaborative governance. Government agencies played an important role to reduce the spread of covid 19 in Taiwan. The government of Taiwan issued five successful strategies i.e a). Infrastructure 
Setting and Organization. b) The Central Epidemic Command Centre (TECC) 2) Resources, Technology and Communication. There were two main activities i.e. a) On-line order system for mask and b) Cellphone Track. 3) Control and Regulation; 4) Collaboration; 5) Public Participation and compliance.

The Government of South Korea succeed to implement collaborative governance. The key to success was the leadership of the national government (Central Government). There were three strategies that was made by the national government i.e. (1) Clarify the roles of the national government, local governments, public health sector, and industry sector in responding to an emergency situation, (2) Expedite the process for laboratories to develop and use unapproved diagnostic test kits, and (3 ) Allow the Korea Centers for Disease Control and Prevention (KCDC) to access extensive personal data from 28 companies, including cellular data, financial data, GPS information, and social network system (SNS) information in the case of a public health emergency [17].

\section{Private Institution}

Private Institution was one of the actors that play significant role to combat covid 19. Most Indonesia's company participated in the fight against covid in Indonesia. This was because the company had to follow law no 40/2007 which regulated the corporate social responsibility (CSR) to the community. This law required all the companies and state-owned enterprises to have a commitment to reduce social and environmental damage caused by corporations. To help Indonesia emerge stronger from this pandemic, the companies can play critical role by altering CSR programs to better respond to their community's needs. Radyati [18]stated that Pertamina helped 1000 micro small and medium enterprises by giving business capital assistance during the pandemic of covid 19 in Java Island.

The role of the private sector in Collaborative Governance in Surabaya Indonesia was stated by Megawati, et al. [14] Hadi [19] on the article of Institute Technology Bandung (ITB) stated that Dexa Medica group donated chloroquine, Hyudrochloroquine and Azitromycin to National disaster Management Agency (NDMA) for all reference hospitals (dedicated to 35.000 patient) on April 17, 2020. Biofarma group donated chloroquine, Personal protective equipment's (PPE), and hand sanitizers to NDMA as well as food to poor people.

However, the company in Indonesia had shown yet good result in reducing pandemic in Indonesia. Indonesia should learn from the successful experience of Taiwan and South Korea. The following paragraph discusses the success of the Private Institution to reduce covid19 in Taiwan and South Korea. The article from Yuen Wai Hung [16]stated that Private Institution was included in the strategy of collaboration from the government of Taiwan. Private Institution did a collaboration strategy. The success of collaboration in Taiwan between government and private institution were conducted in three main activities i.e. a) mask production, b) pharmacist association and c) peddler association.

Choi [17]stated that building partnerships with companies and other private entities were considered to be another critical factor in South Korea's successful response to COVID19. There were 20 biotech/medical companies working together to prevent the pandemic. With the active participation of these biotech companies, South Korea was able to conduct over 145,000 tests by March 5, 2020 and it reached at over 300,000 tests.

The public-private institutions did a collaboration in South Korea i.e. 1) South Korean conglomerates, including LG, Samsung, and Hyundai provided medical facilities and other necessaries such as water, toiletries, and sanitizers to medical staff, and groceries and daily necessities to the quarantined and affected people; 2) The immigration department (for border entry information); 3) The police department (for surveillance camera footage); 4) 
Telecommunication companies (for GPS information); 5) Public/private transport operators (for detailed information on travel routes); 6) Credit card companies (for identifying visited locations through the use of using financial data); 7) Partnering with private companies to develop mobile applications (apps) to show the number of available face masks at nearby locations of the users [17].

\section{Community/Civil Society}

Community can be an individual or society. That helped the government to fight for covid 19. World bank [20]defines civil society as : " the term civil society refers to the wide array of non-governmental and not for profit organization that have a presence in public life, expressing interest and value of their members or others based on ethical, cultural, political, scientific, religious and philanthropic considerations".

According to Yuen Wai Hung [16]the success of Collaborative Governance to reduce covid-19 was on the hand of the civil society and community. Agustino [21]urged that the main factor why there was a high spread of covid 19 because of the ignorance of the society to follow the rule of the government. Therefore, there should be a cooperation between government, communities or civil society and religious leader to fight covid 19 in Indonesia[22]. Some of the Non-Governmental Organization (NGO) and Civil Society Organization (CSO) supported the government to fight the covid 19. The NGOs and CSOs supported the governments were WALHI, YLBI, AJAR, P2D, YLKI, YLBHI, PKBI, Kontras, LBH Masyrakat dan Migrant care [23].

Many strategies were implemented by the government to increase the awareness of the society; however, the result was less effective. Therefore, Indonesia should learn from Taiwan and South Korea. Both countries had proven to increase the active participation of the community to reduce the spread of the covid19. Active participation of the community had shown significant impact to combact the covid 19 in Taiwan[16]. The government of Taiwan had made a good strategy to actively involved the community. The government called this strategy as "public participation and compliance". In this strategy, there were three main activities i.e. a) Virus awareness and mask wearing; b) Whistle blowing and c) VoluntaryAssistance.

The same result was found in the city of South Korea Choi [17] urged that the effectiveness of collaborative governance largely depended on public participation. Some strategies to involve communities such as: 1) The government regards the public as copartners, continually emphasizing that their participation is critical. As a result, almost everyone wears a face mask, avoids going to crowded areas, and takes sanitization measures seriously (e.g., social distancing, carrying hand sanitizers, and washing hands frequently). 2) People's high level of health consciousness and 3) People's trust in the current policies and effectiveness of the overall governance system. In addition, transparent public information and well-planned public campaigns and education, along with their experiences with previous epidemics, have made the public well alert of the situation and better prepared for this type of health crisis[17].

\section{International Actor/Global Actor}

Covid 19 has been a pandemic in the world. Therefore, there should be a global collaboration to end the spread of the virus. We urged the government of Indonesia to involve International actor/Global Company to reduce the effect of Covid 19 in Indonesia. The involvement of International actor was one of the four actors advocated by Ali Farazmand in Sound Governance Theory. 
Farazmand and Carter [7] urged the government to pay attention on four different actors on sound governance i.e. 1) International Actor; 2) Government; 3) Private Institution and 4) Civil Society/community. The following paragraph discusses the role of the international actor to reduce covid-19 in Indonesia. International actor refers to four different global actors i.e. 1) International Institution such as World Health Organization (WHO), United Nation (UN), International Monetary Fund (IMF), World Bank, and Multinational Company etc. 2) International NGO; 3) Bilateral/multilateral Institution; 4) Multinational Corporation[7].

WHO is the most influential global actor to reduce the spread of Covid in Indonesia. The role of the WHO is to give guidance and technical assistance to the countries on how to handle covid 19 worldwide. WHO has formed Covax to ensure the vaccine distribution could be accessible and affordable for all countries in the world. Covax is co-led by Gavi, the coalition for epidemic preparedness innovations (CEPI) and WHO. Its aim is to accelerate the development and manufacture of covid19 vaccines, and to guarantee fair and equitable access for every country in the world [24].

Another actor that plays significant contribution is the multinational corporation. The most significant progress of international actor/global actor was the invention of vaccine covid 19. WHO had published at least 50 companies who are involved in the invention of vaccine covid19. Many multinational companies had reported that they successfully produce vaccine for covid 19. The companies such as Pfizer, Moderna, Oxford University, Sinovac, Sinopharm, Cansiono and many more. Vaccine covid 19 will be one of the most powerful strategy to end covid 19 by forming Herd Immunity. Herd Immunity will be effective if there are at least $70 \%$ of the population are vaccinated [24].

So far, The Ministry of Health $(\mathrm{MoH})$ of Indonesia chose Sinovac as vaccine to be vaccinated to the people of Indonesia based on the decree of directorate general P2P, prevention and control disease [25]. We urged the community to follow the regulation of the government by going to the health facility to be vaccinated to prevent the spread of corona virus in Indonesia.

\section{Conclusions}

a. There were three main actors in Collaborative Governance to reduce covid-19 in Indonesia i.e.. Government, Private Institution and Civil Society. These three actors had significant role to reduce covid-19 in Indonesia.

b. There was another main actor that played crucial role in sound governance to reduce covid-19 in Indonesia i.e. International Actor. WHO is the most influential global actor to reduce the spread of Covid in Indonesia. The role of the WHO is to give guidance and technical assistance to the countries on how to handle covid 19 worldwide. Another actor that plays significant contribution is the multinational corporation. The most significant progress of international companies was the invention of vaccine by international companies such as Pfizer, Moderna, Oxford University, Sinovac, Sinopharm, Cansiono and many more.

\section{Acknowledgement}

We would like to thank you to Beasiswa Dikti for giving us a scholarship in School of Public Administration Hasanuddin University. 


\section{References}

[1] WHO. (2020, 11 March). WHO Director-General's opening remarks at the media briefing on COVID-19. Available: https://www.who.int/director-general/speeches/detail/who-directorgeneral-s-opening-remarks-at-the-media-briefing-on-covid-19---11-march-2020

[2] WHO, "Coronavirus disease (COVID-19) pandemic," ed: World Health Organization, 2020.

[3] WHO, "WHO Coronavirus Disease (COVID-19) Dashboard," World Health Organization, World Health Organization2020.

[4] KEPPRES, "Keputusan Presiden (KEPPRES) tentang Gugus Tugas Percepatan Penanganan Corona Virus Disease 2019 (COVID-19)," in Nomor 7, K. P. R. Indonesia, Ed., ed. INDONESIA, 2020, p. 8.

[5] KEPPRES, "Keputusan Presiden (KEPPRES) tentang Perubahan atas Keputusan Presiden Nomor 7 Tahun 2020 tentang Gugus Tugas Percepatan Penanganan Corona Virus Disease 2019 (Covid-19)," in Nomor 9, K. P. R. Indonesia, Ed., ed. INDONESIA: Pemerintah Pusat, 2020, p. 8 .

[6] C. Ansell and A. Gash, "Collaborative governance in theory and practice," Journal of public administration research and theory, vol. 18, pp. 543-571, 2008.

[7] A. Farazmand and R. Carter, Sound governance: Policy and administrative innovations: Greenwood Publishing Group, 2004.

[8] E. Barnett-Page and J. Thomas, "Methods for the synthesis of qualitative research: a critical review," BMC medical research methodology, vol. 9, pp. 1-11, 2009.

[9] S. L. Smith, "Collaborative approaches to Pacific Northwest fisheries management: The salmon experience," Willamette J. Int'l L. \& Dis. Res., vol. 6, p. 29, 1998.

[10] T. Reilly, "Communities in conflict: Resolving differences through collaborative efforts in environmental planning and human service delivery," J. Soc. \& Soc. Welfare, vol. 25, p. 115, 1998.

[11] S. Connick and J. E. Innes, "Outcomes of collaborative water policy making: Applying complexity thinking to evaluation," Journal of environmental planning and management, vol. 46, pp. 177-197, 2003.

[12] S. Vangen and C. Huxham, "Enacting leadership for collaborative advantage: Dilemmas of ideology and pragmatism in the activities of partnership managers," British journal of management, vol. 14, pp. S61-S76, 2003.

[13] S. R. A. Suhudiyah, "Peran Parlemen dalam Menciptakan Collaborative Governance Berbasis Pendekatan Penta Helix Stakeholder untuk Mengatasi Pandemi Covid-19," ed. Jakarta: Lembaga Ilmu Pengetahuan Indonesia, 2020.

[14] S. Megawati, F. Niswah, and T. A. Oktariyanda, "Collaborative Governance as Handling Efforts of Pandemic Covid-19 in Surabaya City," in 3rd International Conference on Social Sciences (ICSS 2020), 2020, pp. 312-316.

[15] D. Ginanjar, "Peran Pemerintah Daerah pada Penanganan Covid-19," Jurnal Politik Pemerintahan Dharma Praja, vol. 13, p. 17, 2020.

[16] M. C. Yuen Wai Hung, Mara Hansen Staples. (2020, 17 April) Creative Public-Private Collaborations in Taiwan and South Korea Bolster the Fight Against Coronavirus. Stanford Social Innovations Review. Available: https://ssir.org/articles/entry/creative_public_private_collaborations_in_taiwan_and_south_korea bolster_the_fight_against_coronavirus

[17] Y. J. Choi, "The Power of Collaborative Governance: The Case of South Korea Responding to COVID-19 Pandemic," World Medical \& Health Policy, vol. 12, pp. 430-442, 2020.

[18] M. N. Radyati, "Emerging Stronger from Covid-19 with Flexible CSR Programs," ed. Jakarta: Jakarta GLobe, 2020.

[19] D. Hadi. (2020, Universities, Private Sectors and NGOs are Crucial to Fight COVID-19 in Indonesia. Available: https://fa.itb.ac.id/universities-private-sectors-and-ngos-are-crucial-tofight-covid-19-in-indonesia/

[20] World bank, "Defining civil society," vol. 2020, ed: World Bank, 2010. 
[21] L. Agustino, "Analisis Kebijakan Penanganan Wabah Covid-19: Pengalaman Indonesia," Jurnal Borneo Administrator, vol. 16, pp. 253-270, 2020.

[22] S. Syafrida and R. Hartati, "Bersama melawan virus covid 19 di Indonesia," SALAM: Jurnal Sosial Dan Budaya Syar-I, vol. 7, pp. 495-508, 2020.

[23] A. Muchlashin and H. Suyatno, "Peran Civil Society dalam Menghadapi Pandemi Covid-19 di Desa Karangtengah Kecamatan Kemangkon Kabupaten Purbalingga," Islamic Management and Empowerment Journal, vol. 2, 2020.

[24] WHO, "COVAX: Working for global equitable access to COVID-19 vaccines," ed: World Health Organization, 2020.

[25] Dirjen P2P, "Petunjuk Teknis Pelaksanaan Vaksinasi Dalam Rangka Penanggulangan Pandemi Corona Virus Disease 2019," D. J. P. d. P. Penyakit, Ed., ed. Jakarta: Kementerian Kesehatan, 2021. 